\title{
Numerical Analysis of Electrophoretic Protein Patterns of Zymomonas Strains
}

\author{
By J. SWINGS, K. KERSTERS AND J. DE LEY \\ Laboratory of Microbiology and Microbial Genetics, \\ Faculty of Sciences, State University, B9000 Gent, Belgium
}

(Received I4 May 1975)

SUMMARY

Electropherograms of soluble protein from 43 Zymomonas strains were compared, visually and by a quantitative computer-assisted clustering technique. Experimental conditions and mathematical procedures were explored to increase the reproducibility as much as possible. All isolates from British deteriorated beer samples, and from fermenting plant saps from Zaïre, Mexico and Indonesia had very similar electrophoretic protein patterns. There was no noticeable difference between Zymomonas mobilis and $Z$. anaerobia. The protein pattern of the only available strain of $Z$. anaerobia subsp. pomaceae was different.

\section{INTRODUCTION}

Swings \& De Ley (1975) reported on genome similarities within the genus Zymomonas. One strain of Z. mobilis from fermenting sap of Agave americana in Mexico, 33 strains of Zymomonas sp. from Elaeis- and Raphia-palm wines in Zaïre, and four strains of $Z$. anaerobia from beer in England, had almost identical DNA genomes. The genome of one strain of $Z$. anaerobia subsp. pomaceae (the cider-sickness bacillus) isolated from cider in England (Millis, 1956) was distinctly different; it had a DNA relatedness (\% D) of about I9 with the main group. These findings suggested that all strains from the main group are phenotypically very similar, and that the pomaceae strain has some specific phenotypical features. We have now checked this assumption by comparing polyacrylamide gel electropherograms of the soluble proteins and analysing the results by the computer-assisted method described by Kersters \& De Ley (I975).

\section{METHODS}

Bacteria. Most of the strains used have been described previously (Swings \& De Ley, 1975). The new strains are listed in Table $\mathrm{I}$.

Culture conditions. Bacteria were grown, harvested and washed as described by Swings \& De Ley (1975) and Kersters \& De Ley (1975).

Preparation of bacterial extracts. Bacteria were disrupted in a French pressure cell and the extracts prepared as described by Kersters \& De Ley (1975). Since, for unknown reasons, extracts of Zymomonas acidified spontaneously, the cell-free extracts were prepared and the protein concentration was adjusted in $64 \mathrm{mM}$-tris- $\mathrm{HCl}$ buffer $\mathrm{pH} 9 \cdot \mathrm{I} 5$.

Polyacrylamide gel electrophoresis and clustering of strains. Electrophoresis, staining of protein bands, photography and densitometry of the stained gels, normalization and compensation of the densitometer scans, computer-assisted calculation of the Pearson product-moment correlation coefficient $r$, and clustering were performed according to Kersters \& De Ley (1975). For compensation of the normalized scans, seven easily 

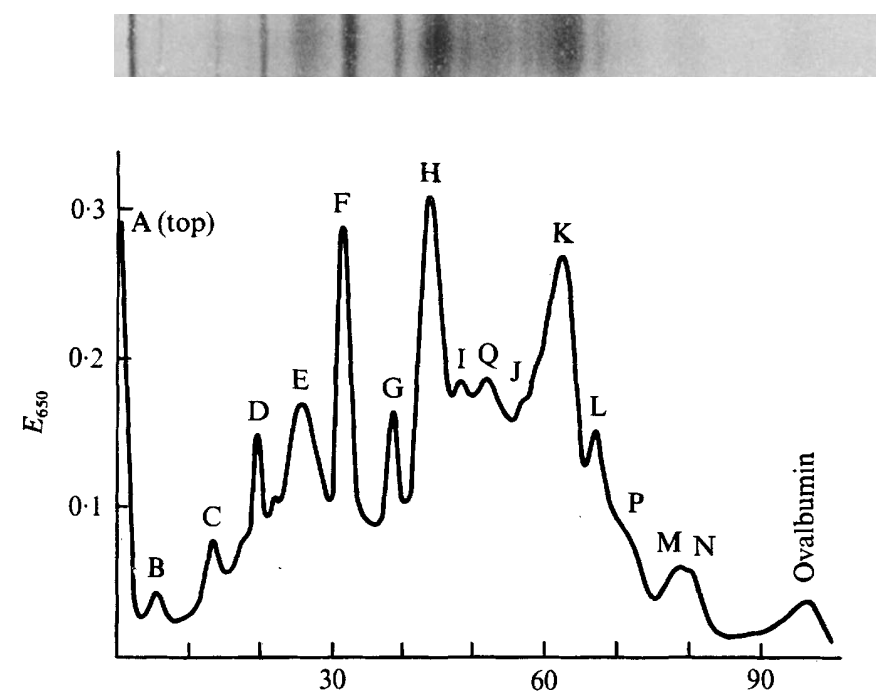

Fig. 1. Typical scanning of the electrophoretic protein pattern of a Zymomonas strain. Strain 70.12 was selected because it displays all peaks. The distance between the top of the gel and the ovalbumin reference peak is divided into 96 equal parts. Each protein peak is designated by a capital letter.

Table I. Origin of the additional Zymomonas strains used

$\overbrace{\begin{array}{c}Z . \text { mobilis } \\ \text { strain 3 Delft }\end{array}}^{\text {Strain designation }} \underbrace{\begin{array}{c}\text { Z. mobilis } \\ \text { strain B70 }\end{array}}_{\begin{array}{c}Z . \text { mobilis } \\ \text { strain 6 Delft }\end{array}}$

$\begin{array}{llll}\begin{array}{l}\text { Isolated from } \\ \text { Place of isolation }\end{array} & \begin{array}{l}\text { Fermenting sap of Arenga } \\ \text { Treub Laboratory, Bogor, } \\ \text { Java, Indonesia }\end{array} & \begin{array}{l}\text { Fresh sap of Arenga (tuak) } \\ \text { University, Bandung, Java, } \\ \text { Indonesia }\end{array} & \begin{array}{c}\text { Infected British ale } \\ \text { Licensed premises, } \\ \text { England }\end{array} \\ \begin{array}{l}\text { Date of isolation } \\ \text { Isolated by }\end{array} & \begin{array}{l}\text { August 1949 } \\ \text { Dr H. G. Derx }\end{array} & \begin{array}{l}\text { I949 } \\ \text { Professor C. O. Schaeffer }\end{array} & \begin{array}{c}\text { Dadds, Martin \& } \\ \text { Carr, I973 }\end{array}\end{array}$

recognizable peaks $\mathrm{B}, \mathrm{C}, \mathrm{D}, \mathrm{F}, \mathrm{G}, \mathrm{H}$ and $\mathrm{K}$ (Fig. I) were selected and aligned in all scans to the same average position, by stretching or narrowing the valley floors. The results were called 'compensated normalized scans'. We also attempted a third method for improvement, in which 13 easily recognizable peaks and shoulders were identified on all scannings. Their height was used for all calculations. This we called the peak method.

\section{RESULTS AND DISCUSSION}

Visual comparison of the stained gels

The protein electropherograms of all Zymomonas strains, except one, were very similar. They consisted mainly of a series of I $_{5}$ bands which varied in intensity and sharpness (Fig. I). The bands of $Z$. anaerobia subsp. pomaceae were located in the same part of the gel column, but with a different pattern. A few strains could be recognized by a specific protein band, e.g. in strains 7.4 and 70.7 band $\mathrm{H}$ was lacking but band $\mathrm{I}$ was stronger than in the other strains, and strain $\mathbf{I}$ had a very strong $\mathbf{P}$ band. Strains isolated in the same area 


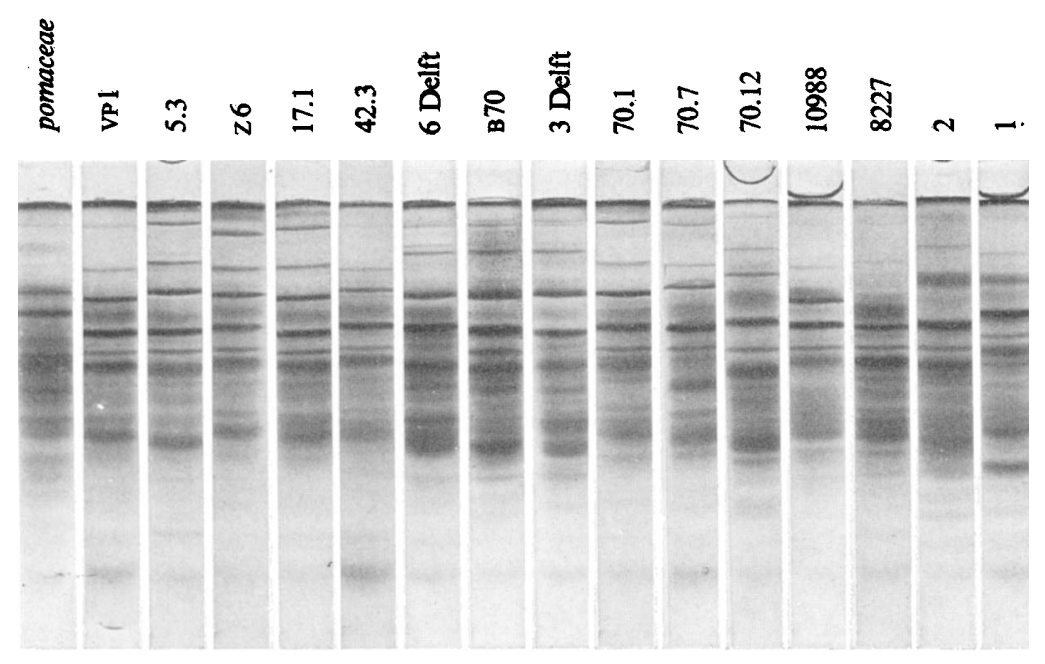

Fig. 2. Sixteen types of normalized protein patterns in Zymomonas.

at the same time had almost identical protein patterns; this was true for strains of each series Z, VP. 5 and I7 isolated in Zaïre (see Table I of Swings \& De Ley, I975). Strains from the 70 series were isolated at different times in 1970 from Elaeis-sap from places in and around Kinshasa, Zaïre; their patterns were not quite the same. Zymomonas anaerobia NCIB8227 and its subculture Queensland 409 had identical protein patterns: bands B, C and D were absent or very weak. The patterns from Z. mobilis ATCCIO988 and its subculture Queensland 4IO were almost identical. Figure 2 shows a series of representative Zymomonas protein patterns.

Visual inspection detected only qualitative similarities between protein band patterns. Quantitative numerical comparisons might detect unsuspected similarities or differences.

\section{Reproducibility of the quantitative electrophoretic method}

Strains cannot be differentiated taxonomically within the limits of reproducibility of the method used. Some aspects of the reproducibility were examined previously with Zymomonas strain z3 (Kersters \& De Ley, I975). However, since extracts from Zymomonas strains displayed very narrow and sharp protein bands (Fig. 2), slight shifts, sometimes hardly visible and unavoidable experimentally, strongly affected the correlation coefficients and thus the reliability of the final clustering. We therefore examined other aspects of the reproducibility more thoroughly.

All results were calculated from compensated normalized scans. Different methods of breakage of bacteria (French pressure cell; Raytheon sonic oscillator; MSK-shaker) did not yield exactly the same gels. We always used the French pressure cell in standardized conditions. Time and temperature of centrifugation, as well as protein concentration and volume of the sample, had to be kept constant.

In the following experiments we used strain $z_{3}$ as a model and checked, at the same time, the effect of repeated electrophoretic runs from the same cell-free extract, the effect of repeated cultures, and how well the reproducibility could be improved by mathematical corrections. Twenty-one gels prepared from five cultures of strain $z_{3}$ grown independently in the same conditions, were compared by each of the three mathematical methods (Fig. 3). The lowest clustering from normalized scans was $r=0.67$, from the peak method it 


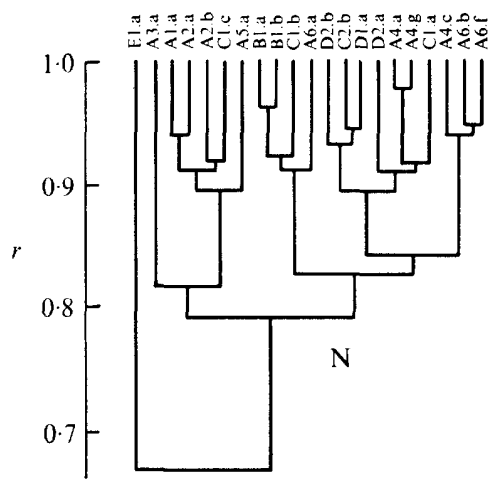

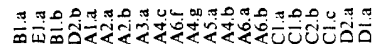
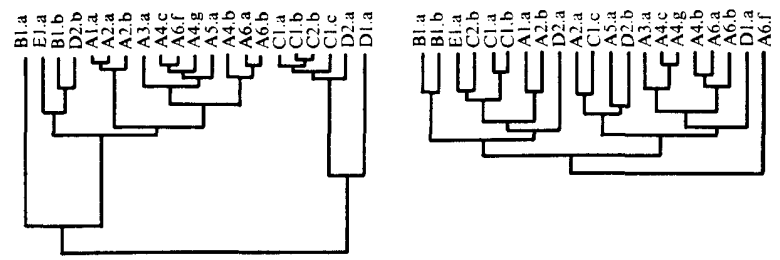

$\mathbf{P}$

$\mathrm{CN}$

Fig. 3. Mathematical improvement of the reproducibility of electropherograms of strain $\mathrm{z3}$. Twenty-one scannings are clustered by the normalized $(\mathrm{N})$, the compensated normalized $(\mathrm{CN})$, and the peak (P) methods. Each gel has a tripartite symbol: independent batches are designated by the letters A, B, C, D and E, separate electrophoresis runs by a number, and the individual gels by small type.

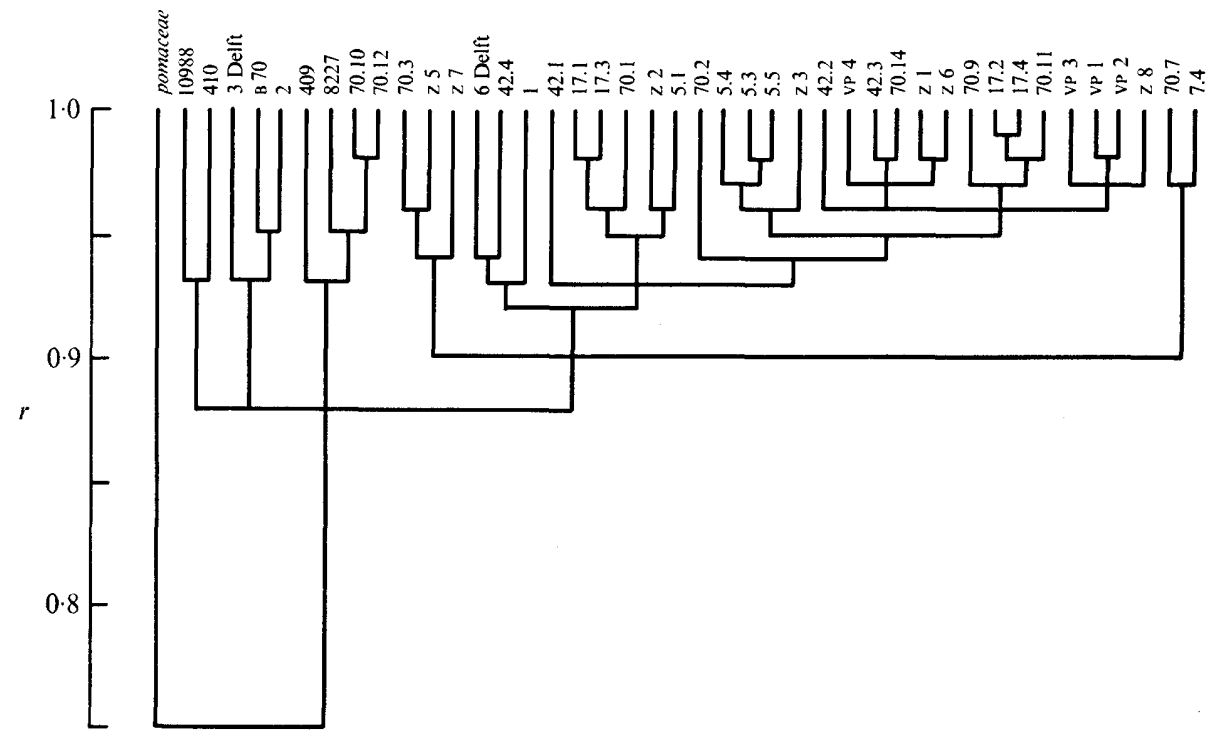

Fig. 4. Quantitative correlation of the gel electropherograms of soluble protein from Zymomonas strains. Polyacrylamide gel electrophoresis and clustering of the correlation coefficients $r$ after normalization and compensation was carried out as described by Kersters \& De Ley (1975). The most typical electropherogram of each strain was selected and used.

was $r=0.84$, and from compensated normalized scans it was $r=0.90$. The third correction method was thus the best. The gels from each culture did not cluster together. The reproducibility of electropherograms from one culture was no higher than from different batches. The remaining variability of the results was thus due to the electrophoretic techniques and not to differences in culturing.

\section{The limits of reproducibility}

Ninety compensated normalized scans from 43 Zymomonas strains were clustered with the unweighted average pair group method. The lower reproducibility limits were: for 


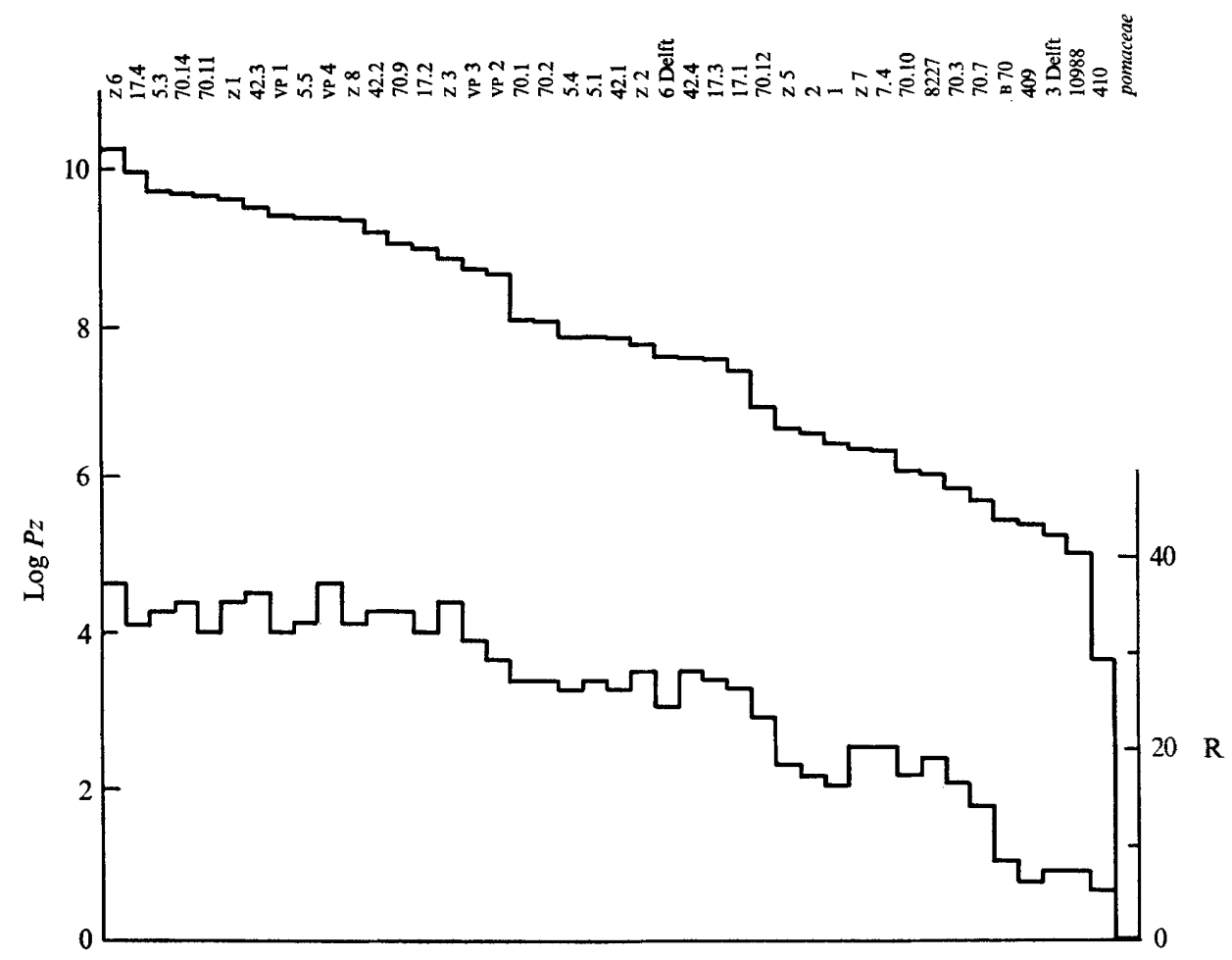

Fig. 5. The homogeneity of Zymomonas protein electropherograms and the most representative strain $\mathrm{z6}$. The ranking order $\mathrm{R}$ is the number of correlation coefficients $r \geqslant 0.9$. The hierarchical order is the product $P$ of the $z$ values (the inverse hyperbolic tangent of $r$ ) of each strain. It is expressed logarithmically for convenience.

strain z3 (2I gels), $r=0.88$; strain 3 Delft (9 scans), $r=0.9 \mathrm{I}$; strain B70 (8 scans), $r=0.96$; strain 6 Delft (5 scans), $r=0.97$; strains 5.I, 5.4, 5.3, 70.14 and 2 (2 scans each), $r=0.9 \mathrm{I}$, $0.94,0.94,0.95$ and 0.96 , respectively; the pomaceae organism (4 scans) $r=0.9 \mathrm{I}$. From the above data and the complete clustering (not given here) it followed that above the level of $r=0.88$ no taxonomic differentiations are possible in Zymomonas by this method.

\section{Numerical analysis of the electrophoretic protein patterns of 43 Zymomonas strains}

When several gels were available from one strain, the one with the highest product of $z$ values was selected as the most typical (Silvestri et al., I962). The $z$-transformation is the inverse hyperbolic tangent of the correlation coefficient $r$ (Rohlf $\&$ Sokal, I969). In the final analysis one gel per strain was used. The results are shown in Fig. 4. All strains, except one, clustered together at or above $r=0.88$, the limit of taxonomic differentiation. The quantitative analysis confirmed the visual inspection: all but one of the Zymomonas strains had a very similar, and sometimes identical, soluble-protein composition, whatever their source. The highly correlated protein patterns of the strains examined reflected their close genetic resemblance, shown by DNA-DNA homologies, \% GC (Swings \& De Ley, 1975) and numerical analysis of the phenotype (De Ley \& Swings, unpublished). We calculated the homogeneity of the cluster and the most representative protein electropherogram by a slight modification of the methods of Rogers \& Tanimoto (I960) and of 
Silvestri et al. (1962). We defined the value of the ranking order $\mathrm{R}$ as the number of electropherograms with which the electropherogram under consideration had a value of $r \geqslant 0.90$. The hierarchical order $\mathbf{H}$ of each electropherogram is the product of its $z$ values. The results are shown in Fig. 5. All strains formed a rather homogeneous cloud, except the pomaceae organism. A central nucleus of 17 strains (z6, $\mathrm{zI}, \mathrm{z8}, \mathrm{z3}, \mathrm{I7.4}, \mathrm{I7.2}, 5.3,5.5,70.14,70.1 \mathrm{I}$, $70.9,42.3,42.2$, VPI, VP2, VP3, VP4) displayed very typical protein electropherograms. Strain $\mathrm{z} 6$ had the most typical protein electropherogram, with both the highest $\mathrm{H}$ and $\mathrm{R}$ values. It was the centroid of the system.

The type strain of $Z$. mobilis ÀTCCI0988 is a member of the large conglomerate of strains. Shimwell (1937) proposed no type strain for $Z$. anaerobia. An authentic cotype of $Z$. anaerobia, strain D364 (Sneath \& Skerman, 1966), is no longer available (P. H. A. Sneath, personal communication). We are not aware of other existing type strains of this species. There are no noticeable differences between the protein patterns of strains called $Z$. mobilis and $Z$. anaerobia. Therefore we propose to unite all these organisms in one species $Z$. mobilis.

The 'cider-sickness bacillus', $Z$. anaerobia subsp. pomaceae, is rather different both in genome-DNA relatedness, in \% GC (Swings \& De Ley, 1975) and in protein pattern.

J.D.L. thanks the Fonds voor Kollektief Fundamenteel Onderzoek for research and personnel grants. J.S. thanks the Instituut tot Aanmoediging van het Wetenschappelijk Onderzoek in Nijverheid en Landbouw for a research grant. We are very indebted to Dr M. J. S. Dadds, Bath, Somerset, Dr P. A. Martin, Allied Breweries Ltd, England, and to Ir J. van der Toorn, Lab. Microbiologie, T.H. Delft, The Netherlands, for kindly providing strains, and in particular to the latter for very valuable information on the origin of several strains.

\section{REFERENCES}

Dadds, M. J. S., Martin, P. A. Carr, J. G. (I973). The doubtful status of the species Zymomonas anaerobia and $Z$. mobilis. Journal of Applied Bacteriology 36, $531-539$.

KERSTERS, K. \& DE LEY, J. (I975). Identification and grouping of bacteria by numerical analysis of their electrophoretic protein patterns. Journal of General Microbiology 87, 333-342.

Millis, N. F. (1956). A study of the cider-sickness bacillus - a new variety of Zymomonas anaerobia. Journal of General Microbiology 15, 521-528.

Rogers, D. J. \& TANimoto, T. T. (I960). A computer program for classifying plants. Science, New York I32, II I 5-III 8 .

Rohlf, F. J. \& Sokal, R. R. (1969). Statistical Tables, p. 143. San Francisco: Freeman.

SHIMWELl, J. L. (1937). A study of a new type of beer disease bacterium (Achromobacter anaerobium sp.nov.) producing alcoholic fermentation of glucose. Journal of the Institute of Brewing 43, 507-509.

Silvestri, L., Turri, M., Hill, L. R. \& Gilardi, E. (I962). A quantitative approach to the systematics of actinomycetes based on overall similarity. Symposia of the Society for General Microbiology 12, 333-360.

SNeAth, P. H. A. \& Skerman, V. B. D. (I966). A list of type and reference strains of bacteria. International Journal of Systematic Bacteriology $\mathrm{r6}, \mathrm{r}-\mathrm{I} 33$.

Swings, J. \& DE LEY, J. (1975). Genome DNA of the genus Zymomonas Kluyver and van Niel I936; base composition, size and similarities. International Journal of Systematic Bacteriology. 25, 327-328. 